\title{
Meningkatkan Hasil Belajar PPKn Menggunakan Model Pembelajaran Examples Non Examples pada Siswa Kelas VIIIE SMP Negeri 6 Salatiga
}

\author{
Nani Mediatati \\ Universitas Kristen Satya Wacana Salatiga, Indonesia
}

\section{Abstract}

In real conditions of PPkn learning in class VIII E SMPN 6 Salatiga, the teachers only use the lecture method in the delivery of teaching materials and students are passive, so based on the results of the evaluation, there were 19 students $(67.85 \%)$ have not yet reached Minimum Completeness Criteria $\geq 76$. Based on these problems, its were need to be repaired by Learning model examples of non examples to improve PPKn learning outcomes in class VIII E. Classroom action research is conducted in two cycles and each cycle is carried out through planning, action, observation, and reflection. There were 28 students of class VIII E as the research subject. Methods of data collection are documentation, observation, and test. Technique of data analysis uses quantitative descriptive analysis by comparing the percentage of completeness PPKn learning outcomes before and after the action in cycle 1 and cycle 2. Indicator of research success is learning outcomes corresponding completed PPKn Minimum Completeness Criteria $\geq 76$ achieved to $85 \%$ of all students. Result of study shows that increasing outcome of PPKN learning after using examples of non examples learning model. Prior to the act of learning, there were only 9 students (32.15\%), which reached Minimum Completeness Criteria $\geq 76$, increased to 19 students $(67.85 \%)$ in cycle 1 and 25 students $(89.29 \%)$ in the second cycle after the act of learning. Based on the results of this study concluded that using of non examples examples learning model can improve outcomes of PPKn learning in class VIII E SMPN 6 Salatiga.
\end{abstract}

Keywords:

Learning Outcomes,

Examples Of Non

Examples Learning

Model

\section{Pendahuluan}

Menurut Slavin (1990:10) salah satu permasalahan yang sering terjadi selama proses pembelajaran yaitu kurang terlibatnya siswa dalam kegiatan belajar mengajar sehingga suasana kelas jadi membosankan dan kegiatan belajar menjadi tidak nyaman. Masalah itu disebabkan karena guru dalam penyajian materi pelajaran tidak dapat membuat siswa merasa termotivasi, siswa kurang terlibat langsung dalam proses pembelajaran, sehingga siswa sulit memahami materi yang diajarkan yang berdampak pada hasil belajar siswa yang kurang maksimal. Oleh sebab itu, guru perlu melakukan upaya perbaikan dalam proses pembelajaran agar siswa terlibat aktif dalam pembelajaran sehingga dapat meningkatkan hasil belajarnya.Sebagaimana dijelaskan oleh Oemar Hamalik (1994: 44) bahwa guru harus dapat melakukan suatu inovasi yang menyangkut tugasnya sebagai pendidik/pengajar. Inovasi yang dilakukan guru diharapkan mampu meningkatkan hasil belajar siswa. Salah satu inovasi yang harus dilakukan guru adalah memilih dan mengembangkan metode mengajar yang sesuai dengan materi yang diajarkan dan karakteristik siswa, agar pembelajaran dapat berlangsung secara efektif dan tidak membosankan. Metode mengajar adalah suatu cara atau teknik yang dipakai oleh guru dalam menyajikan bahan ajar kepada siswa untuk mencapai tujuan pengajaran.

Kondisi pembelajaran yang kurang melibatkan siswa secara aktif dan memotivasi siswa ini juga terjadi dalam pembelajaran PPKn. Menurut Sumarsono,dkk (2008:38) kenyataan di lapangan dalam pembelajaran PPKn guru dalam penyampaian materi cenderung menggunakan metode konvensional yang

\footnotetext{
* Corresponding author.

E-mail Addresses: nani_mediatati@ymail.com (Nani Mediatati)
} 
berpusat pada guru (teacher oriented) sehingga kurang memotivasi siswa untuk aktif belajar. Interaksi antara siswa yang satu dengan yang lain juga sangat kurang, hal ini disebabkan karena siswa kurang terbiasa diajak untuk bekerjasama atau diskusi dalam proses pembelajaran. Metode yang digunakan hanya berkisar pada pemberian ceramah, tanya jawab, penugasan. Akibatnya dalam mempelajari materi PPKn siswa cenderung kurang semangat dan PPKn dianggap sebagai pelajaran yang membosankan. Hasil observasi terhadap pembelajaran PPKn materi Sumpah Pemuda di kelas VIII E SMP Negeri 6 Salatiga juga menunjukkan kondisi yang sama, siswa kurang semangat dan aktif dalam pembelajaran PPKn karena guru hanya menggunakan metode ceramah dan tanya jawab di akhir pelajaran. Akibatnya hasil belajar siswa yang ditunjukkan oleh nilai ulangan harian baik secara individual maupun rata-rata kelas masih rendah. Berdasarkan KKM yang ditentukan sekolah yaitu 76 hanya 9 siswa (32,15\%) yang telah mencapai KKM dan 19 siswa $(67,85 \%)$ belum mencapai KKM. Nilai rata rata kelas jugadi bawah KKM yaitu 69,82. Keberhasilan pembelajaran PPKn sangat bergantung kepada usaha guru untuk membangkitkan aktivitas belajar siswa dalam proses pembelajaran. Aktivitas dalam proses pembelajaran ini merupakan rangkaian kegiatan yang meliputi keaktifan siswa dalam mengikuti pelajaran, bertanya hal-hal yang belum jelas, mencatat, mendengar, berpikir, membaca, dan segala kegiatan yang dilakukan yang dapat menunjang tercapainya hasil belajar secara maksimal. Oleh karena itu guru perlu melakukan perubahan dengan cara menggunakan metode yang variatif dan inovatif, sebagaimana dikemukakan oleh Hamzah B. Uno (2011:17) yaitu dengan "mengubah dari sekedar metode ceramah dengan berbagai variasi metode yang lebih relevan dengan tujuan pembelajaran, memperkecil kebiasaan cara belajar peserta yang baru merasa belajar dan puas kalau banyak mendengarkan dan menerima informasi (diceramahi) guru, atau baru belajar kalau ada guru". Model pembelajaran konvensional harus diubah supaya siswa tidak merasa bosan dalam mengikuti pelajaran PPKn, siswa lebih aktif dalam pembelajaran tidak lagi hanya sekedar menerima informasi atau diceramahi guru, tetapi bisa memberikan informasi kepada teman-temannya.

Model pembelajaran yang diharapkan dapat memotivasi siswa untuk aktif dalam proses pembelajaran serta dapat meningkatkan hasil belajar PPKn adalah model pembelajaran examples non examples. Menurut Etin Solihatin \& Raharjo (2005:22) pembelajaran examples non examples adalah suatu proses belajar mengajar di dalam kelas di mana siswa diberikan contoh-contoh gambar yang menarik dan berhubungan dengan materi pembelajaran. Kemudian siswa diminta untuk mendiskusikan secara kelompok. Tugas guru adalah merangsang untuk berfikir kritis dalam memecahkan masalah yang ada, serta mengarahkan siswa untuk berani menyampaikan pendapat, bertanya dan menjawab serta menyimpulkan permasalahan. Selanjutnya menurut Rochyandi, Yadi (2004:11) model pembelajaran examples non examples adalah model pembelajaran yang mengaktifkan siswa dengan cara guru menempelkan contoh gambar- gambar yang sesuai dengan tujuan pembelajaran dan gambar lain yang relevan dengan tujuan pembelajaran, kemudian siswa disuruh untuk menganalisisnya dan mendiskusikan hasil analisisnya sehingga siswa dapat membuat konsep esensial. Penggunaan media gambar ini disusun dan dirancang agar siswa dapat menganalisis gambar tersebut menjadi sebuah bentuk diskripsi singkat mengenai apa yang ada di dalam gambar. Gambar tersebut dapat ditayangkan melalui OHP atauproyektor. Dengan memusatkan perhatian siswa terhadap pembelajaran dengan menggunakan media gambar diharapkan akan dapat mendorong siswa untuk menuju pemahaman yang lebih dalam mengenai materi yang ada. Adapun langkah-langkah pembelajaran examples non examples menurut Agus Suprijono (2010:125) meliputi (1) guru mempersiapkan gambar- gambar sesuai dengan tujuan pembelajaran, (2) guru menempelkan gambar di papan atau ditayangkan lewat OHP atau LCD, (3) guru memberi petunjuk dan memberi kesempatan kepada siswa untuk memperhatikan/ menganalisa gambar, (4) melalui diskusi kelompok 2-3 orang siswa atau lebih , hasil diskusi dari analisa gambar tersebut dicatat pada kertas, (5) tiap kelompok diberi kesempatan membacakan hasil diskusinya, (6) mulai dari komentar/ hasil diskusi siswa, guru mulai menjelaskan materi sesuai dengan tujuan yang ingin dicapai, (7) membuat kesimpulan. Melalui langkah-langkah tersebut maka model examples non examples mempunyai keunggulan antara lain: (1) siswa dapat mamahami materi dengan lebih jelas dengan menampilkan contoh- contoh kongkrit dengan visualisasi gambar, (2) siswa akan lebih berpikir kritis terhadap suatu pokok permasalahan yang dihadapi, (3) siswa terlibat langsung dalam kegiatan untuk menemukan suatu konsep secara langsung dari hasil analisis siswa, (4) siswa dapat diberi kesempatan untuk mengemukakan pendapatnya di depan kelas. Selaras dengan pendapat Hamzah B.Uno, (2011:80) bahwa dengan menggunakan model pembelajaran examples non examples akan memotivasi siswa untuk aktif dalam pembelajaran dan mendapatkan hasil belajar yang maksimal. Kegiatan pembelajaran menjadi menyenangkan serta tidak membosankan. Hasil belajar merupakan suatu indikator dari perubahan yang terjadi pada diri siswa setelah mengalami proses belajar dimana untuk mengungkapnya digunakan suatu alat penilaian yang ditetapkan sekolah oleh guru (Soemantri ,2001:1). Hasil belajar ini berupa nilai yang diperoleh siswa setelah mengikuti proses pembelajaran melalui tes yang dilakukan oleh guru. Penelitian yang dilakukan oleh Gede Sutarta, dkk. (2014) menunjukkan bahwa penerapan model pembelajaran example non 
example dapat meningkatkan aktivitas dan hasil belajar pada mata pelajaran PKn siswa kelas VIII F semester II SMP Negeri 5 Singaraja Kecamatan Buleleng Kabupaten Buleleng tahun pelajaran 2013/2014. Pada siklus I persentase hasil belajar mencapai 70,11\% dan pada siklus II persentase hasil belajar meningkat menjadi 80,22\%. Dengan demikian hasil belajar meningkat sebesar 10,11\%.

Demikian juga hasil penelitian Rosalina, Selvia (2014) menunjukkan bahwa penerapan model pembelajaran examples non examples dapat meningkatkan motivasi dan hasil belajar siswa pada mata pelajaran Pendidikan Kewarganegaraan di kelas VIII B SMP Negeri 1 Kejayan Kabupaten Pasuruan semester II tahun pelajaran 2013/2014. Hasil belajar siswa pada siklus I sebesar 29 siswa tidak tuntas dan 7 siswa tuntas dengan nilai rata-rata kelas sebesar 71, meningkat pada siklus II menjadi 6 siswa tidak tuntas belajar dan yang tuntas 32 siswa dengan nilai rata-rata kelas sebesar 86. Berdasarkan kajian teori dan hasil penelitian tersebut maka dilakukan penelitian tindakan kelas untuk meningkatkan hasil belajar dalam mata pelajaran PPKn materi keberagaman dalam bingkai Bhinneka Tunggal Ika dengan menggunakan model pembelajaran examples non examples pada siswa Kelas VIII E SMP Negeri 6 Salatiga Semester 2 Tahun ajaran 2014/2015.

\section{Metode Penelitian}

Jenis penelitian yang digunakan adalah Penelitian Tindakan Kelas dengan tujuan untuk meningkatkan hasil belajar siswa dalam mata pelajaran PPKn pada materi keberagaman dalam bingkai Bhinneka Tunggal Ika dengan menggunakan model pembelajaran examples non examples. Model penelitian tindakan kelas yang digunakan dengan sistem spiral/siklus yang terdiri dari empat tahapan yaitu penyusunan rencana (planing), pelaksanaan tindakan (action), observasi (observation), dan refleksi (reflection) ( Kemmis dan Mc Taggart dalam Kunandar, 2008: 120). Pelaksanaan penelitian dilakukan pada semester genap tahun pelajaran 2014/2015 dari bulan Februari sampai dengan Mei 2015 dalam 2 siklus dan setiap siklus terdiri dari 2 kali pertemuan. Subyek penelitian adalah siswa kelas VIII E SMP Negeri 6 Salatiga yang berjumlah 28 orang.Teknik pengumpulan data menggunakan dokumentasi, observasi dan tes yang telah diuji validitas dan reliabilitasnya.Teknik analisis data menggunakan teknik deskriptif kuantitatif dengan membandingkan prosentase ketuntasan hasil belajar siswa sebelum tindakan dan setelah tindakan pada siklus I dan siklus II. Penelitian dikatakan berhasil apabila hasil belajar siswadalam mata pelajaran PPKn mencapai Kriteria Ketuntasan Minimum (KKM) $\geq 76$ secara klasikal tercapai dan secara individual dicapai oleh 85\% dari seluruh siswa kelas VIII E.

\section{Hasil Penelitian dan Pembahasan Hasil Penelitian}

Pembelajaran PPKn pada siklus I di kelas VIII E dilakukan 2 kali pertemuan. Pada tahap perencanaan disusun RPP dengan materi makna keberagaman dalam bingkai Bhineka Tunggal Ika, dipersiapkan gambar-gambar yang berkaitan dengan materi, disusun lembar observasi untuk mengamati kegiatan guru dan siswa selama proses pembelajaran serta disusun soal tes yang akan diberikan pada akhir pertemuan kedua untuk mengetahui ketuntasan hasil belajar siswa setelah diterapkan model pembelajaran examples non examples.

Dalam pelaksanaan pembelajaran khususnya dalam kegiatan inti guru membagi siswa dalam 7 kelompok masing- masing kelompok terdiri dari 4 orang siswa. Selanjutnya guru memberikan penjelasan singkat tentang materi pembelajaran yaitu makna keberagaman dalam bingkai Bhineka Tunggal Ika. Kemudian guru menampilkan gambar- gambar yang berkaitan dengan materi pembelajaran lewat LCD. Masing-masing kelompok diminta untuk mengamati dan menganalisis gambar tersebut. Siswa berfikir bersama dalam kelompok, berdiskusi dan menyatukan pendapat terhadap informasi yang telah didapat tentang makna keberagaman dalam bingkai Bhineka Tunggal Ika. Ketika siswa melakukan kerja kelornpok, guru memotivasi dan memberikan bantuan apabila ada siswa atau kelompok yang mengalami kesulitan dalam mengerjakan tugas. Masing-masing kelompok kemudian mempresentasikan hasil kerja kelompok di depan kelas secara bergantian. Setelah semua kelompok selesai presentasi, siswa bersama guru membahas jawaban yang diperoleh, guru meluruskan kesalahan pemahaman siswa, memberikan penguatandan bersama siswa menyimpulkan materi. Dalam kegiatan akhir guru melakukan evaluasi/tes untuk mengetahui kemampuan siswa dalam menguasai materi pembelajaran.

Berdasarkan hasil observasi terhadap kegiatan guru dan siswa dalam proses pembelajaran yang dilakukan oleh observer, guru masih kurang bisa menguasai kelas karena masih banyak siswa yang ramai sendiri dan kurang aktif dalam diskusi kelompok. Siswa juga kurang aktif saat kegiatan presentasi kelompok karena siswa masih kelihatan canggung untuk membacakan hasil kerja kelompok, sehingga kegiatan presentasi didominasi oleh guru. Hanya sebagian kecil siswa yang berani memberikan pertanyaan atau tanggapan terhadap kelompok yang presentasi. 
Ketuntasan hasil belajar PPKn berdasarkan nilai tes setelah dilaksanakan pembelajaran dengan model examples non examples mengalami peningkatan, namun masih ada 9 siswa (32,15\%) yang mendapat nilai di bawah $\mathrm{KKM} \geq 76$, seperti tertera dalam tabel berikut ini.

\begin{tabular}{|c|c|c|c|}
\hline No & Kriteria & Jumlah & $\begin{array}{c}\text { Persentase } \\
(\%)\end{array}$ \\
\hline 1 & Siswa tidak tuntas & 9 & 32,15 \\
\hline 2 & Siswa tuntas & 19 & 67,85 \\
\hline \multicolumn{2}{|c|}{ Jumlah } & 28 & 100 \\
\hline \multicolumn{2}{|c|}{ Nilai Maksimum } & \multicolumn{2}{|c|}{86} \\
\hline \multicolumn{2}{|c|}{ Nilai Minimum } & \multicolumn{2}{|c|}{60} \\
\hline \multicolumn{2}{|c|}{ Rata-rata } & \multicolumn{2}{|c|}{76,89} \\
\hline
\end{tabular}

Berdasarkan tabel 1 menunjukkan bahwa pada siklus 1 siswa yang tuntas hasil belajarnya mencapai 67,85\%, sedangkan siswa yang tidak tuntas mencapai 32,15\%. Bila dibandingkan dengan sebelum dilakukan tindakan, ada peningkatan ketuntasan hasil belajar siswa setelah dilakukan tindakanpada siklus I, yaitu dari $32,15 \%$ yang tuntas mencapai KKM $\geq 76$ menjadi $67,85 \%$ yang mencapai $\mathrm{KKM} \geq 76$. Nilai rata rata kelas juga meningkat dari 69,82 menjadi 76,89. Namun demikian peningkatan ketuntasan hasil belajar secara individual ini belum mencapai 85\%dari seluruh siswa sehingga perlu dilakukan tindakan perbaikan pembelajaran pada siklus II.

Hasil refleksi terhadap proses dan hasil pembelajaran menunjukkan perlunya tindakan perbaikan pembelajaran pada siklus II untuk meningkatkan ketuntasan hasil belajar sesuai target yang diharapkan. Guru harus bisa mengkondusifkan kelas agar tidak ramai dan memotivasi siswa untuk aktif dalam diskusi dengan cara guru mendatangi setiap kelompok, mengarahkan dan membimbing dalam pengerjaan tugas kelompok. Gambar yang ditayangkan lewat LCD untuk dianalisis harus lebih menarik dengan warna dan suara. Guru juga harus memberikan motivasi pada kelompok untuk lebih aktif dalam presentasi, dengan memberikan tugas kepada kelompok lain bertanya atau memberikan tanggapan kepada kelompok presentasi. Disamping itu guru harus memandu jalannya diskusi kelas agar tidak terjadi pemahaman yang salah terhadap materi pembelajaran yang didiskusikan. Dengan demikian siswa terlibat aktif dalam proses pembelajaran, memahami materi dengan baik sehingga diharapkan dapat meningkatkan hasil belajarnya.

Pembelajaran pada siklus II dilakukan 2 kali pertemuan. Pada tahap perencanaan ini disusun RPP dengan materi kerjasama dalam masyarakat yang beragam dalam bingkai Bhinneka Tunggal Ika, dipersiapkan gambar-gambar yang menarik berkaitan dengan materi, disusun lembar observasi untuk mengamati kegiatan guru dan siswa selama proses pembelajaran serta disusun soal tes yang akan diberikan pada akhir pertemuan kedua untuk mengetahui ketuntasan hasil belajar siswa setelah diterapkan model pembelajaran examples non examples dengan perbaikan berdasarkan refleksi dari siklus 1.

Sama dengan siklus 1 pada tahap pelaksanaan pembelajaran khususnya dalam kegiatan inti guru membagi siswa dalam 7 kelompok masing- masing kelompok terdiri dari 4 orang siswa. Selanjutnya guru memberikan penjelasan singkat tentang materi pembelajaran yaitu tentang kerjasama dalam masyarakat yang beragam dalam bingkai Bhinneka Tunggal Ika. Kemudian guru menampilkan gambar- gambar yang berkaitan dengan materi pembelajaran lewat LCD. Masing-masing kelompok diminta untuk mengamati dan menganalisis gambar tersebut. Siswa berfikir bersama dalam kelompok, berdiskusi dan menyatukan pendapat terhadap informasi yang telah didapat tentang kerjasama dalam masyarakat yang beragam dalam bingkai Bhineka Tunggal Ika. Ketika siswa melakukan kerja kelompok, guru mendatangi setiap kelompok, mengarahkan dan membimbing dalam pengerjaan tugas kelompok, guru memotivasi dan memberikan bantuan apabila ada siswa atau kelompok yang mengalami kesulitan dalam mengerjakan tugas. Masing-masing kelompok kemudian mempresentasikan hasil kerja kelompok di depan kelas secara bergantian dipandu oleh guru. Kelompok yang tidak presentasi harus memberikan pertanyaan atau tanggapan terhadap kelompok yang presentasi sehingga diskusi berjalan secara aktif. Setelah semua kelompok selesai presentasi, siswa bersama guru membahas jawaban yang diperoleh, guru meluruskan kesalahan pemahaman siswa, memberikan penguatan dan bersama siswa menyimpulkan materi. Dalam kegiatan akhir guru melakukan evaluasi/tes untuk mengetahui kemampuan siswa dalam menguasai materi pembelajaran.

Hasil observasi terhadap kegiatan guru dan siswa dalam proses pembelajaran yang dilakukan oleh observer menunjukkan bahwa guru dapat mengelola kelas dengan baik, siswa tidak ramai sendiri dan aktif dalam diskusi kelompok. Siswa juga aktif saat kegiatan presentasi kelompok karena tanya jawab 
berjalan dengan baik antara kelompok presentasi dan kelompok yang tidak presentasi. Sebagian besar siswa berani memberikan pendapat, pertanyaan atau tanggapan terhadap kelompok yang presentasi.

Ketuntasan hasil belajar PPKn berdasarkan nilai tespada siklus 2 mengalami peningkatanlagi jika dibandingkan dengan ketuntasan hasil belajar pada siklus I, seperti tertera dalam tabel berikut ini.

Tabel 2. Ketuntasan Hasil Belajar PPKn Siswa Kelas VIII E pada Siklus II

\begin{tabular}{|c|c|c|c|}
\hline No & Kriteria & Jumlah & $\begin{array}{c}\text { Persentase } \\
(\%)\end{array}$ \\
\hline 1 & Siswa tidak tuntas & 3 & 10,71 \\
\hline 2 & Siswa tuntas & 25 & 89,29 \\
\hline Jum & & 28 & 100 \\
\hline Nila & Maksimum & \multicolumn{2}{|c|}{90} \\
\hline Nila & Minimum & \multicolumn{2}{|c|}{73} \\
\hline Rato & rata & \multicolumn{2}{|c|}{83,28} \\
\hline
\end{tabular}

Berdasarkan tabel 2 di atas menunjukkan bahwa siswa yang tuntas hasil belajarnya mencapai $89,29 \%$, sedangkan siswa yang tidak tuntas hasil belajarnya hanya 10,71\%. Bila dibandingkan dengan ketuntasan hasil belajarpada siklus I, ada peningkatan pada siklus II, dari 67,85\% menjadi 89,29\% yang tuntas mencapai $\mathrm{KKM} \geq 76$. Nilai rata rata kelas juga meningkat dari 76,89 menjadi 83,28. Ketuntasan hasil belajar siswa mencapai KKM $\geq 76$ secara klasikal tercapai dan secara individual sudah mencapai lebih dari 85\% siswa sehingga penelitian tindakan kelas dikatakan berhasil.

Refleksi terhadap proses dan hasil pembelajaran menunjukkan bahwa tindakan perbaikan pembelajaran pada siklus II telah berhasil meningkatkan ketuntasan hasil belajar sesuai target yang diharapkan karena siswa terlibat aktif dalam proses pembelajaran, siswa memahami materi melalui menemukan sendiri konsep dari análisis gambar secara kongkrit berdasarkan diskusi secara kelompok maupun diskusi kelas yang dipandu oleh guru, sehingga dapat mencapai hasil belajar yang optimal. Dengan demikian dapat disimpulkan bahwa pembelajaran menggunakan model pembelajaran examples non examples dapat meningkatkan hasil belajar siswa dalam mata pelajaran PPKn pada materi keberagaman dalam bingkai Bhinneka Tunggal Ika di kelas VIII E SMP Negeri 6 Salatiga Semester II tahun pelajaran 2014/2015.

\section{Pembahasan}

Berdasarkan hasil penelitian menunjukkan bahwa pembelajaran menggunakan model examples non examples dapat meningkatkan hasil belajar siswa dalam mata pelajaran PPKn pada materi keberagaman dalam bingkai Bhinneka Tunggal Ika di kelas VIII E SMP Negeri 6 Salatiga secara signifikan. Ketuntasan hasil belajar siswa mengalami peningkatan setelah dilakukan pembelajaran dengan menggunakan model pembelajaran examples non examples. Sebelum dilakukan pembelajaran dengan model examples non examples dalam arti masih digunakan metode ceramah ketuntasan hasil belajar siswa mencapai KKM $\geq 76$ hanya dicapai oleh 9 siswa (32,15\%) dengan nilai rata-rata kelas 69,82, setelah dilakukan pembelajaran dengan model examples non examples ketuntasan hasil belajar siswa mencapai $\mathrm{KKM} \geq 76$ dicapai oleh 19 siswa (67,85\%) dengan nilai rata-rata kelas 76,89 pada siklus 1 dan pada siklus 2 meningkat menjadi 25 siswa $(89,29 \%)$ dengan nilai rata- rata 83,28. Melalui penerapan langkahlangkah model pembelajaran examples non examples oleh guru, siswa terdorong untuk aktif dalam proses pembelajaran. Karena siswa harus dapat memahami materi pembelajaran dengan menemukan suatu konsep secara langsung lewat analisis gambar secara kongkrit melalui kerja kelompok maupun diskusi kelas. Guru hanya bertugas sebagai fasilitator yang mengarahkan siswa dalam kerja kelompok, memandu diskusi kelas, dan memperjelas konsep atau permasalahan yang didiskusikan, sehingga siswa benar-benar dapat memahami materi pembelajaran dengan baik. Walaupun pada awal pembelajaran dengan menggunakan model examples non examples ini ( pada siklus 1), siswa cenderung ramai dan kurang aktif dalam proses pembelajaran. Hal ini disebabkan karena gambar yang ditayangkan kurang menarik dan guru kurang memotivasi dan mengarahkan siswa dalam kerja kelompok maupun diskusi kelas. Sehingga siswa kurang berani mengemukakan pendapatnya, bertanya, maupun menanggapi pendapat teman/kelompok dalam diskusi. Oleh karena itu hasil belajar siswa dari hasil tes yang menunjukkan kemampuan siswa dalam memahami materi pembelajaran kurang optimal. Ketuntasan hasil belajar sesuai $\mathrm{KKM} \geq 76$ baru dicapai oleh 19 siswa $(67,85 \%)$ dan 9siswa $(32,15 \%)$ belum tuntas. Nilai rata-rata kelas 76,89. Namun demikian setelah dilakukan tindakan perbaikan dalam penerapan model examples non examples pada siklus 2 dengan cara guru mendatangi setiap kelompok, mengarahkan dan membimbing dalam pengerjaan tugas kelompok. Gambar yang ditayangkan lewat LCD untuk dianalisis lebih menarik 
dengan warna dan suara. Guru juga memberikan motivasi pada kelompok untuk lebih aktif dalam presentasi, dengan memberikan tugas kepada kelompok lain bertanya atau memberikan tanggapan kepada kelompok presentasi, serta memandu jalannya diskusi kelas. Maka siswa menjadi aktif dalam proses pembelajaran dan mampu memahami materi pembelajaran dengan baik. Hasil belajar siswa dari hasil tes menunjukkan adanya peningkatan secara signifikan. Ketuntasan hasil belajar sesuai KKM $\geq 76$ dicapai oleh 25 siswa $(89,29 \%)$ dengan nilai rata- rata 83,28.

Selaras dengan pendapat Hamzah B.Uno, (2011:80) bahwa dengan menggunakan model pembelajaran examples non examples akan memotivasi siswa untuk aktif dalam pembelajaran dan mendapatkan hasil belajar yang maksimal. Kegiatan pembelajaran menjadi menyenangkan serta tidak membosankan. Demikian juga pendapat Agus Suprijono (2010:125) yang menyatakan bahwa model examples non examples mempunyai keunggulan antara lain: (1) siswa dapat mamahami materi dengan lebih jelas dengan menampilkan contoh- contoh kongkrit dengan visualisasi gambar, (2) siswa akan lebih berpikir kritis terhadap suatu pokok permasalahan yang dihadapi, (3) siswa terlibat langsung dalam kegiatan untuk menemukan suatu konsep secara langsung dari hasil analisis siswa, dan (4) siswa dapat diberi kesempatan untuk mengemukakan pendapatnya di depan kelas.

Hasil penelitian ini sejalan dengan hasil penelitian terdahulu yang dilakukan Gede Sutarta, dkk. dan Rosalina, Selvia. (2014) bahwa penerapan model pembelajaran examples non examples dapat meningkatkan hasil belajar siswa dalam mata pelajaran PPKn di Kelas VIII SMP Negeri 5 Singaraja Kabupaten Buleleng dan SMP Negeri 1 Kejayan Kabupaten Pasuruan.

\section{Simpulan}

Berdasarkan analisis data dan pembahasan hasil penelitian, maka dapat disimpulkan bahwa pembelajaran PPKn pada materi keberagaman dalam bingkai Bhinneka Tunggal Ika dengan menggunakan model examples non examples dapat meningkatkan hasil belajar siswa kelas VIII E SMP Negeri 6 Salatiga. Hasil belajar siswa yang tuntas mencapai KKM $\geq 76$ secara individual sebelum dilakukan tindakan pembelajaran dengan menggunakan model examples non examples hanya dicapai oleh 9 siswa $(32,15 \%)$, namun setelah dilakukan tindakan pembelajaran dengan menggunakan model examples non examples meningkat menjadi 19 siswa (67,85\%) pada siklus I dan 25 siswa (89,29\%) pada siklus II sesuai KKM 76. Hasil belajar siswa secara klasikal berdasarkan nilai rata-rata kelas juga meningkat dari 69,82 sebelum tindakan menjadi 76,89 pada siklus I dan 83,28 pada siklus II setelah dilakukan tindakan pembelajaran dengan model examples non examples.

Berdasarkan simpulan di atas, maka disarankan bagi guru-guru PPKn untuk menggunakan model pembelajaran examples non examples dalam mengajarkan materi PPKn agar siswa terlibat aktif dalam proses pembelajaran dan dapat meningkatkan hasil belajarnya.

\section{Daftar Pustaka}

Agus Suprijono. 2010. Cooperatif Learning Teori dan Aplikasi. Yogyakarta: Pustaka Pelajar Etin Solihatin\& Raharjo. 2005. Cooperative Learning. Jakarta: Bumi Aksara.

Gede Sutarta, dkk. 2014. Penerapan Model Pembelajaran Example Non Example untuk Meningkatkan Aktivitas dan Hasil Belajar Pada Mata Pelajaran PKn siswa kelas VIII F Semester II SMP Negeri 5 Singaraja Kecamatan Buleleng Kabupaten Buleleng tahun pelajaran 2013/2014. Jurnal Jurusan Pendidikan PKn Vol 2, No 1 (2014)

Hamzah B. Uno. 2011. Profesi Kependidikan. Jakarta: Bumi Aksara.

Kunandar. 2011. Langkah Mudah Penelitian Tindakan Kelas sebagai Pengembangan Profesi Guru. Jakarta: Raja Grafindo Persada.

Rosalina, Selvia. 2014. Penerapan Model Pembelajaran Example non Example Untuk Meningkatkan Motivasi Dan Hasil Belajar Siswa Pada Mata Pelajaran Pendidikan Kewarganegaraan di kelas VIII B di SMP Negeri 1 Kejayan Kabupaten Pasuruan. Skripsi Tidak Diterbitkan. Malang: Jurusan Hukum dan Kewarganegaraan, Program Studi S1 Pendidikan Pancasila dan Kewarganegaraan, Fakultas Ilmu Sosial, Universitas Negeri Malang.

Slavin R., 1990, Cooperative Learning: Theory, Research and Practice, Englewoods Cliff, NJ: Prentice-Hall.

Somantri, Muhammad Numan. 2001. Menggagas Pembaharuan Pendidikan IPS. Bandung: PT Remaja Rosdakarya.

Oemar Hamalik. 1994. Kurikulum dan Pembelajaran. Bandung: Bumi Aksara

Rochyandi, Yadi. 2004. Tips Aplikasi Pakem (Pembelajaran Aktif, Kreatif, Efektif,dan Menyenangkan. Jogyakarta: Diva Press.

Sumarsono, dkk. 2008. Pendidikan Kewarganegaraan. Jakarta: PT Gramedia Pustaka Utama 